\title{
Analisis Pemahaman Konsep Mahasiswa Pendidikan Fisika Universitas Sriwijaya pada Materi Gravitasi Newton dengan Menggunakan NGCI Dan CRI Termodifikasi
}

\author{
Anita Yuza Rahayu, Syuhendri Syuhendri, Ida Sriyanti \\ Pendidkan Fisika, Jurusan PMIPA, FKIP Universitas Sriwijaya \\ Anitayuzarahayu07@gmail.com
}

\begin{abstract}
This research aims to analyze about conceptual understanding and misconceptions on material Newtonian Gravity of students physics education Sriwijaya University. Data collected by using test NGCI (Newtonian Gravity Concept Inventory), CRI (Certainty of Response Index), and Interview to discribed types of conceptual understanding students'. Analysis methods data used Descriptive qualitative technique. Based on the analysis CRI, this research find 28,51\% student understand the concept, 4,68 \% understand the concept but not sure, 27,9\% misconception, and 25,62 \% not understand the concept. The most misconception occurs in sub concept the relations of mass to the gravitational force that is 49,65\%. This research can be used for basic research increase student conceptual understanding.
\end{abstract}

Keywords : Conceptual Understanding, Misconception, CRI( Certainty of response Index), Newtonian Gravity

his is an open access article distributed under the Creative Commons 4.0 Attribution License, which permits unrestricted use, distribution, and reproduction in any medium, provided the original work is properly cited. 02018 by author and Universitas Negeri Padang.

\section{PENDAHULUAN}

Fisika merupakan cabang Ilmu Pengetahuan Alam (IPA) yang mempelajari tentang alam dan seisinya serta perubahanperubahan yang terjadi di dalamnya. Pembelajaran fisika mencakup fakta, konsep, prinsip, hukum, dan teori yang harus dikuasai secara mendalam untuk dapat menerapkan dalam penyelesaian masalah (Setyani, 2016). Akibatnya, dalam proses pembelajaran fisika perlu adanya proses penemuan secara mandiri oleh siswa agar pem belajaran yang di peroleh siswa tersimpan sebagai pengetahuan yang lebih bermakna.

Pembelajaran fisika mengarahkan dan menekankan pada memahami proses bagaimana pengetahuan yang diperoleh dapat digunakan dengan baik. Tujuan utama pembelajaran fisika adalah membantu siswa dalam memperoleh pengetahuan dasar dari prinsip dan konsep (Kallesta \& Erfan, 2017). Hakikat tujuan pembelajaran fisika adalah untuk mengantarkan pemahaman siswa menguasai konsep-konsep dan keterkaitannya untuk dapat memecahkan masalah terkait dalam kehidupan sehari-hari (Zahran, 2017). Kata menguasai memiliki arti bahwa melalui pembelajaran fisika siswa diharapkan tidak sekedar tahu dan hafal tentang konsep-konsep, tetapi juga mengerti dan memahami konsep-konsep tersebut dan dapat menghubungkan keterkaitan suatu konsep dengan konsep lain.

Pemahaman termasuk kedalam kemampuan kognitif tingkat rendah yang setingkat lebih tinggi dari pengetahuan. Sudjana (2011) menyatakan kemampuan yang dimiliki siswa pada tingkat ini adalah kemampuan memperoleh makna dari materi pelajaran yang telah dipelajari. Siswa diharapkan dapat memahami apa yang diajarkan, mengetahui apa yang akan dikomunikasikan dan dapat memanfaatkan pembelajaran. Hal ini sejalan dengan pendapat Johnson dalam Marlis (2015) yang mengungkapkan bahwa pemahaman adalah kemampuan untuk menerangkan sesuatu dengan kata-kata sendiri. Konsep merupakan bagian dasar yang harus dipahami setiap siswa dalam pembelajaran fisika (Agustina, 2016). Menurut Salvin (2011) konsep adalah gagasan abstrak yang digeneralisasi dari contoh-contoh fisik. Konsep atau kategori yang tersimpan dalam pikiran disebut skema (Syuhendri, 2010). Skema ini diibaratkan sebagai berkas yang ada di dalam suatu file. Skema akan terus berkembang sebagai hasil interkasi manusia dengan lingkungannya. Berkas akan terus di tambahkan ke dalam file atau diperbaiki sesuai dengan kebutuhan. Ada dua cara bagaimana skema ini dapat berkembang yaitu asimilasi dan akomodasi. Dengan demikian konsep merupa 
kan hasil dari pemikiran seseorang atau kelompok untuk merumuskan suatu prinsip.

Pengetahuan akan suatu konsep sangatlah penting bagi tiap siswa. Setiap siswa memiliki konsepsi sendiri pada saat memasuki pem belajaran. Kerangka kerja konseptual yang siswa miliki saat memasuki pembelajaran fisika memiliki dampak mendalam pada materi yang akan mereka pelajari (Klammer, 1998). Dengan demikian, pengetahuan akan suatu konsep sangat dipengaruhi oleh konsep awal yang dimiliki oleh siswa saat memasuki pembelajaran fisika. Hidayati (2016) berpendapat bahwa pengetahuan yang dimiliki oleh siswa dapat mereka peroleh dari proses pendidikan maupun pengalaman mereka di kehidupan sehari-hari. Oleh karena itu konsepsi yang dimiliki oleh siswa akan sangat beragam, karena setiap siswa memiliki konsepsi masing-masing saat memasuki pembelajaran.

Sebenarnya fisika adalah pelajaran yang menarik, karena berkaitan dengan kehidupan sehari-hari. Akan tetapi dalam beberapa penelitian menyatakan bahwa siswa masih mengalami kesulitan dalam memahami konsepkonsep fisika. Banyak penelitian yang juga menunjukkan bahwa masalah pemahaman konsep tersebar luas di kalangan siswa (Saleh, 2011). Hal ini dikarenakan fisika merupakan mata pelajaran yang banyak menuntut intelektualitas yang cukup tinggi sehingga sebagian besar siswa mengalami kesulitan dalam mempelajarinya. Akibatnya seringkali menim bulkan masalah pada saat proses pembelajaran fisika berlangsung (Jumini, 2017). Menurut Syuhendri (2014) kemampuan siswa dalam menyelesaiakn soal hitungan merupakan hal yang paling menonjol didalam proses pembelajaran sebab mereka dilatih dengan pembelajaran yang menekankan pada perhitungan sehingga mereka terampil meng gunakan rumus tetapi mengalami kesulitan dalam menyelesaikan soal tipe aplikasi misalnya analisis dan sintesis.

Pemahaman mahasiswa sebagai calon guru dalam menguasai konsep-konsep fisika akan mempengaruhi tercapainya tujuan pendidik an dalam proses belajar dan pembelajaran. Mahasiswa memiliki konsep awal yang berasal dari pengalaman dan pengetahuan dari lingkungan yang selanjutnya bertahan dan mengganggu pemikiran mahasiswa (Yunita, 2017). Akibatnya, tujuan pendidikan dalam porses belajar dan pembelajaran akan tidak dapat terwujud dan terhambat. Oleh karena itu mahasiswa sebagai calon guru harus memahami konsep-konsep yang sudah ditentukan dan lebih bijaksana dalam menentukan model atau strategi pembelajaran yang akan digunakan dalam proses belajar dan pembelajaran. Adapun karakteristik penyiapan calon guru fisika harus memenuhi standar sebagai berikut: (1) mempelajari fisika dengan metode yang sama ketika ia mengajar, (2) mendapatkan pengetahuan tentang bagaimana siswa belajar dan bagaimana mereka mempelajari fisika, (3) terlibat dalam lingkungan pembelajaran yang sama dengan lingkungan yang hendak ia ciptakan ketika mengajar, (4) tuntas dalam penguasaan teknologi, metode, keterampilan yang akan mereka gunakan di kelas, (5) mempelajari cara melibatkan siswanya dalam praktek kerja ilmiah, (6) memahami konsepkonsep serta penerapannya secara fleksibel, (7) memahami proses.

Konsep-konsep pada topik gravitasi newton berisi mengenai konsep yang abstrak dan merupakan sistem benda yang cukup besar. Selain itu, di dalam topic gravitasi juga mempelajari gerakan di luar angkasa, dan bagaimana benda langit bisa bergerak. Ada beberapa penelitian mengenai pemahaman konsep materi gravitasi yang diantara nya dilakukan oleh Abell, dkk (2001) yang menunjukkan bahwa banyak orang tidak memiliki pemahaman tentang konsep ilmu bumi dan ruang angkasa. Penelitian sebelumnya mengungkapkan pemahaman konsep mahasiswa yang beranggapan bahwa gravitasi adalah kekuatan yang membuat segala benda jatuh ke arah pusat bumi (Palmer, 2001). Palmer juga menemukan miskonsepsi yang dialami oleh siswa berpikir satelit tidak bisa jatuh ke lautan karena air tidak memiliki gravitasi. Mahasiswa juga beranggapan bahwa seseorang harus meninggalkan atmosfir bumi agar bisa merasakan gaya gravitasi nol dari bumi (Williamson, 2013). Hal lain ditemukan oleh Williamson bahwa banyak mahasiswa tidak mengerti dari mana gravitasi muncul (Williamson, 2012). Sebagian besar penelitian pada materi gravitasi berfokus pada siswa di sekolah, tetapi beberapa penelitian telah menun jukkan bahwa tidak hanya siswa tetapi juga calon guru dan guru juga memiliki banyak kesalahpahaman konsep pada materi gravitasi (Go“nen, 2008). 
Untuk optimalisasi pembelajaran maka diperlukan upaya untuk mengidentifikasi pemahaman konsep mahasiswa, apakah mahasiswa memiliki konsep yang benar, atau mengalami miskonsepsi, dan kurang pengetahuan. Hal ini sejalan dengan pendapat (Syuhendri, Andriani, \& Taufiq, 2019) yang berpendapat bahwa untuk mengembangkan instruksi pembelajaran fisika yang efektif, informasi detail tentang kesalahpahaman siswa penting untuk diketahui. Williamson (2016) mengembangkan tes pilihan ganda 26 butir soal yang disebut dengan Newtonian Gravity Concept Iventory (NGCI) untuk mengetahui tingkat pemahaman konsep mahasiswa fisika dalam menafsirkan konsep gravitasi newton. Berdasarkan penelitian yang dilakukan oleh Williamson (2016) instrumen NGCI telah teruji reliabilitas dan validitasnya. NGCI dapat memberikan informasi mengenai kesulitan mahasiswa dalam memahami konsep mengenai gravitasi newton. Williamson menemukan mahasiswa menerapkan beberapa bentuk penalaran kuantitatif ketika menentukan besarnya gravitasi. Hal ini menunjukkan bahwa NGCI baik digunakan untuk melihat bagaimana kesulitan mahasiswa dalam memahami konsep gravitasi newton. Respon mahasiswa terhadap NGCI menunjukan intuisi cara berpikir mahasiswa yang mungkin atau tidak mungkin sependapat dengan Newton.

Penelitian menggunakan instrumen NGCI untuk mengetahui pemahaman konsep mahasiswa pada materi gravitasi newton masih sedikit dilakukan. Padahal menurut Syuhendri (2014) analisis pemahaman konsep adalah suatu hal yang harus dilakukan sebelum upaya belajar lebih lanjut. Dengan menganalisis pemahaman konsep secara detail diharapkan dapat menentukan strategi pembelajaran konseptual di dalam kelas yang tepat (Syuhendri, 2018).

Melihat masih rendahnya pemahaman konsep mahasiswa dari penelitian sebelumnya mengenai materi gravitasi newton, serta belum pernah penelitian pemahaman konsep mengenai gravitasi newton di kota Palembang. Peneliti tertarik untuk melakukan penelitian ini karena ingin melihat bagaimana pemahaman konsep mahasiswa pendidikan fisika Universitas Sriwjaya pada materi gravitasi newton. Hasan (dalam Syuhendri, 2013) mengajukan cara yang sederhana untuk membedakan konsepsi peserta didik, yaitu dengan menggunakan the Certainty of Respond Index (CRI) pada jawaban responden terhadap soal pilihan ganda khusus pemahaman konsep pada materi pelajaran. Lebih lanjut, Syuhendri (2014) menjelaskan bahwa CRI merupakan instrumen yang baik digunakan untuk membedakan konsepsi seseorang, apakah memiliki konsepsi yang benar, kurang pengetahuan atau mengalami miskonsepsi. CRI adalah instrumen yang baik digunakan untuk mengidentifikasi miskonsepsi siswa karena CRI memiliki indeks kepastian jawaban siswa yang disertakan pada setiap butir soal. CRI tidak akan berarti kalau tidak ada soal untuk mengidentifikasi konsep. Soal identifikasi konsep bersifat tes-diagnosa yang berbeda dengan soal mengukur pengetahuan materi subyek. Soal dikembangkan dengan berbagai langkah dan uji coba berkali-kali sampai bisa memetakan struktur konsepsi responden yang diuji.

\section{METODE PENELITIAN}

Penelitian ini termasuk penelitian deskriptif kuantitatif. Dengan metode ini, peneliti memaparkan data yang telah diperoleh dan menganalisanya sehingga dapat mengetahui gambaran tentang pemahaman konsep maha siswa pendidikan fisika Universitas Sriwijaya pada konsep gravitasi newton.

Teknik pengumpulan data yang digunakan dalam penelitian ii adalah teknik tes. Teknik tes yang digunakan adalah dengan menggunakan instrument tes NGCI (Newtonian Gravity Concept Inventory).

Williamson (2013) mengembangkan tes pilihan ganda berbasis penelitian 26 butir soal yang disebut NGCI (Newtonian Gravity Concept Inventory) untuk menguji kemampuan pemahaman konsep siswa terhadap materi gravitasi newton. Instrumen NGCI dikembangkan berdasarkan konsep yang diidentifikasi, diuji, dan direvisi tentang gravitasi newton berdasarkan literatur penelitian yang dirancang untuk memunculkan tanggapan yang kaya dan beragam dari siswa. Instrumen NGCI oleh peneliti dilakukan validasi terjemahan bahasa ke dalam bahasa Indonesia oleh validator ahli terjemahan. Jumlah responden yang di teliti ada sebanyak 43 mahasiswa.

Tabel Indikator soal NGCI

\begin{tabular}{|c|c|c|}
\hline No. & Konsep Gravitasi Newton & Nomor Soal \\
\hline 1. & Arah Gaya Gravitasi & $2,5,10,12$, \\
& & 26 \\
\hline 2. & Besar Gaya Gravitasi & $6,9,13,21$ \\
\hline 3. & Hubungan Massa terhadap & $18,20,25$ \\
\hline
\end{tabular}




\begin{tabular}{|c|c|c|}
\hline & Gaya gravitasi & \\
\hline 4. & $\begin{array}{l}\text { Hubungan Jarak terhadap Gaya } \\
\text { Gravitasi }\end{array}$ & $4,23,24$ \\
\hline 5. & $\begin{array}{l}\text { Hubungan Jarak dan Massa } \\
\text { terhadap Besar Gaya Gravitasi }\end{array}$ & $\begin{array}{c}3,7,16,19, \\
22\end{array}$ \\
\hline 6. & $\begin{array}{c}\text { Besar Gaya Gravitasi tidak } \\
\text { terpengaruh oleh hal lain }\end{array}$ & $\begin{array}{c}1,8,11,14 \\
15,17\end{array}$ \\
\hline
\end{tabular}

\section{Teknik Analisis Data}

Dalam penelitian yang telah dilakukan, peneliti menganalisis tingkat pemahaman konsep mahasiswa dengan menggunakan tes multiple choice dengan alasan terbuka. Instrumen soal yang digunakan merupakan soal yang telah valid. Penelitian ini dilakukan dengan tujuan untuk mengetahui tingkat pemahaman konsep mahasiswa, maka metode yang digunakan untuk menghitung dan menganalisis data tes menggunakan metode CRI termodifikasi. CRI merupakan ukuran derajat kepastian mahasiswa dalam menjawab setiap soal yang diberikan. Secara umum, CRI biasanya berdasarkan pada suatu skala yang tetap, dalam penelitian yang digunakan dalah skala enam (0-5) sebagai berikut:

Tabel Skala CRI dan Kriteria

\begin{tabular}{|c|c|}
\hline CRI & Kriteria \\
\hline $\mathbf{0}$ & $\begin{array}{c}\text { (Totally guessed answer) } \\
\text { Jika dalam menjawab soal 100\% ditebak }\end{array}$ \\
\hline $\mathbf{1}$ & $\begin{array}{c}\text { (Almost guessed) } \\
\text { Jika dalam menajwab soal persentase } \\
\text { tebakan antara 75-99\% }\end{array}$ \\
\hline $\mathbf{2}$ & $\begin{array}{c}\text { (Not sure) } \\
\text { Jika dalam menjawab soal persentase } \\
\text { tebakan antara 50-74\% }\end{array}$ \\
\hline $\mathbf{3}$ & $\begin{array}{c}\text { (Sure) } \\
\text { Jika dalam menjawab soal persentase } \\
\text { tebakan antara 25-49\% }\end{array}$ \\
\hline $\mathbf{4}$ & $\begin{array}{c}\text { (Almost Certain) } \\
\text { tebakan 1\%-24\% }\end{array}$ \\
\hline $\mathbf{5}$ & $\begin{array}{c}\text { (Certain) } \\
\text { Jika dalam menjawab soal persentase } \\
\end{array}$ \\
\hline
\end{tabular}

(Hasan, 1999)

Penelitian menggunakan soal pilihan ganda dengan alasan terbuka, mahasiswa diminta untuk menjawab pertanyaan dengan memilih pilihan jawaban dengan memberikan alasan dari persoalan dan memberikan skor CRI. Dari jawaban yang diberikan mahasiswa peneliti dapat menganalisiskeyakinan mahasiswa dengan prinsip, hukum, maupun aturan yang telah dipelajari mahasiswa sebelumnya. Untuk menetukan kategori pemahaman konsep digunakan metode CRI termodifikasi. Kemudian dapat diketahui tingkat kemampuan mahasiswa dalam memahami suatu konsep.

\section{Tabel Kriteria CRI Termodifikasi}

\begin{tabular}{|c|c|c|c|}
\hline $\begin{array}{c}\text { Pilihan } \\
\text { Jawaban }\end{array}$ & Alasan & $\begin{array}{c}\text { Nilai } \\
\text { CRI }\end{array}$ & Kategori \\
\hline Benar & Benar & $>2,5$ & Paham Konsep \\
\hline Benar & Benar & $<2,5$ & $\begin{array}{c}\text { Paham Konsep } \\
\text { tetapi tidak yakin } \\
\text { dengan jawabannya }\end{array}$ \\
\hline Benar & Salah & $>2,5$ & Miskonsepsi \\
\hline Benar & Salah & $<2,5$ & $\begin{array}{c}\text { Tidak Paham } \\
\text { Konsep }\end{array}$ \\
\hline Salah & Benar & $>2,5$ & Miskonsepsi \\
\hline Salah & Benar & $<2,5$ & $\begin{array}{c}\text { Tidak Paham } \\
\text { Konsep }\end{array}$ \\
\hline Salah & Salah & $>2,5$ & Miskonsepsi \\
\hline Salah & Salah & $<2,5$ & $\begin{array}{c}\text { Tidak Paham } \\
\text { Konsep }\end{array}$ \\
\hline
\end{tabular}

Adapun langkah-langkah dalam menganalisis data hasil penelitian adalah sebagai berikut.

1. Data jawaban mahasiswa dikelompok berdasarkan konsep pada instrumen NGCI

2. Mencari jawaban mahasiswa per butir soal dari setiap konseo serta mengkombinasikan pilihan jawaban dan alasan kemudian ditabulasi skor jawaban berdasarkan konsep instrumen NGCI

3. Menentukan data jawaban CRI mahasiswa dan dikelompokkan berdasarkan konsep instrumen NGCI

4. Menentukan empat kategori pemahaman konsep (paham konsep, paham konsep tetapi tidak yakin, miskonsepsi, dan tidak paham konsep) yang terdapat pada tabel 3.3.

5. Menghitung frekuensi jawaban mahasiswa

6. Menentukan persentase empat kategori pemahaman konsep mahasiswa tiap-tiap soal dengan rumus

$$
P=\frac{f}{N} x 100 \%
$$

(Sudjana, 2013) 


\section{HASIL DAN PEMBAHASAN Deskripsi Pelaksanaan Penlitian}

Penelitian ini dilaksanakan di Pendidikan

Fisika Universitas Sriwijaya tepatnya pada mahasiswa semester 4 (mahasiswa yang sudah menempuh mata kuliah fisika dasar) kelas

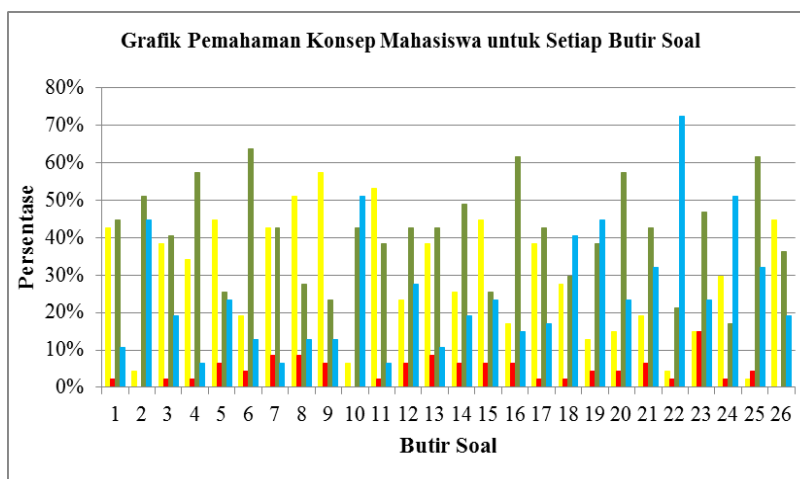

KETERANGAN: PK (Paham Konsep), PKTY (Paham Konsep tetapi Tidak Yakin), M(Miskonsepsi), TPK (Tidak

$$
\square \mathrm{PK} \square \mathrm{PKTTY} \quad \mathrm{M} \quad \text { - }
$$

Gambar. Grafik Pemahaman Konsep Mahasiswa untuk Setiap Butir Soal

Indralaya dan Kelas Palembang tahun akademik 2018/2019. Penelitian di kelas Indralaya dilaksanakan pada tanggal 22 Februari 2019 dan kelas Palembang dilaksanakan pada tanggal 25 Februari 2019.

\section{Data Hasil Penelitian}

Berikut data hasil penelitian yang telah dilakukan. Data hasil penelitian yang diperoleh dalam penelitian ini meliputi data hasil tes dan data CRI termodifikasi yang dipersentasikandan disajikan dalam bentuk grafik serta data hasil wawancara.

Analisa Data

Analisa data dilakukan dengan cara mencari rata-rata pemahaman konsep Mahasiswa, dengan mengkombinasikan pilihan jawaban dan alasan mahasiswa kemudian ditabulasi skor jawaban berdasarkan konsep instrument NGCI, lalu menentukan data jawaban CRI mahasiswa dan dikelompokkan berdasarkan konsep instrument NGCI.

Hasil skor rata-rata pemahaman konsep mahasiswa beragam, yakni $28,51 \%$ paham konsep, 4,68 \% paham konsep tetapi tidak yakin, 41,19\% miskonsepsi, dan 25,62\% tidak paham konsep. Berikut adalah grafik rata-rata pemahaman konsep mahasiswa.

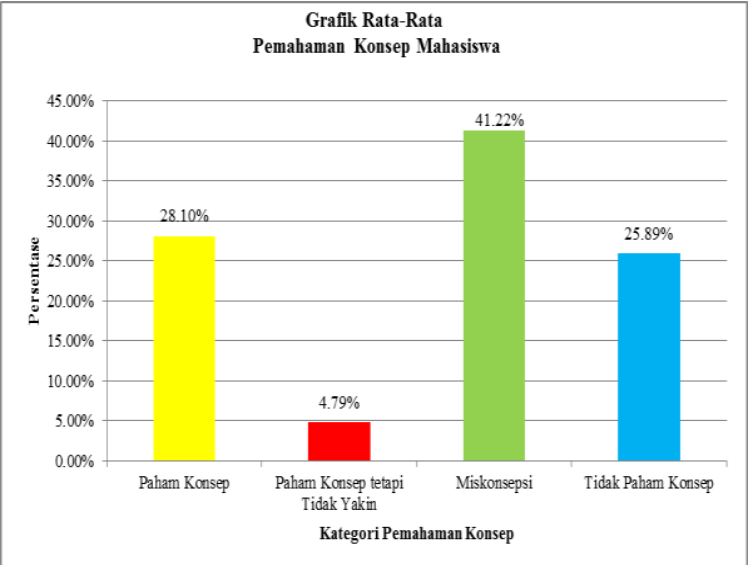

Gambar 2. Grafik Rata-Rata Pemahaman konsep mahasiswa

Hasil data tes yang telah diperoleh dari mahasiswa Pendidikan Fisika Universitas Sriwijaya dianalisis jawaban beserta alasannya kemudian dikelompokkan menjadi empat kategori pemahaman berdasarkan konsep yang terdapat pada instrumen NGCI. Berikut grafik persentase pemahaman konsep mahasiswa berdasarkan konsep instrument NGCI.

Jika pemahaman konsep pada setiap butir soal disajikan dalam bentuk grafik berdasarkan kategori pemahaman konsep, paham konsep tetapi tidak yakin, miskonsepsi, tidak paham konsep hasilnya dapat dilihat pada grafik berikut.

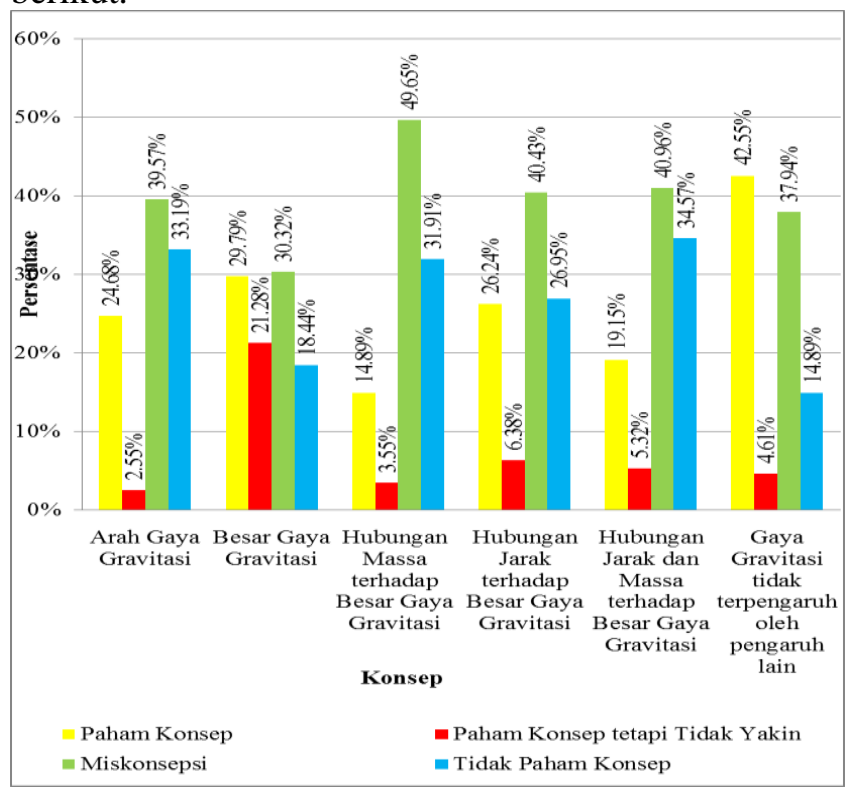

Gambar 3. pemahaman konsep, paham konsep tetapi tidak yakin, miskonsepsi, tidak paham konsep

Pada grafik diatas dapat dilihat bahwa miskonsepsi tertinggi terjadi pada soal nomor 6 pada konsep besar gaya gravitasi yaitu sebesar $63,38 \%$. Miskonsepsi terendah terjadi pada soal 
nomor 24 pada konsep hubungan jarak dan gayagravitasi dengan persentase sebesar 17,02 $\%$. Namun yang sangat mengejutkan adalah pada soal nomor 22 konsep gaya gravitasi tidak mempengaruhi pada suatu keadaan mahasiswa yang tidak paham konsep sebesar 72,34 \%. Hal yang sama terjadi pada konsep arah gaya gravitasi nomor 10 dan hubungan jarak dan gaya gravitasi nomor 24 sebesar 51,06 \% mengalami tidak paham konsep.

Dari analisa data yang telah dilakukan dengan instrumen NGCI yang berjumlah 26 soal menggunakan CRI termodifikasi diperoleh persentase pemahaman konsep mahasiswa Pendidikan Fisika Universitas Sriwijaya pada konsep Gravitasi Newton beragam, yaitu pada persentase paham konsep 28,10 \%, paham konsep tetapi tidak yakin 4,79\%, miskonsepsi $41,22 \%$, dan tidak paham konsep 25,89\%. Hasil penelitian ini sejalan dengan beberapa penelitian yang dilakukan oleh peneliti lain diantaranya adalah penelitian yang dilakukan oleh Widodo \& Suhandi pada tahun 2017 mengungkapkan bahwa lebih dari $40 \%$ mahasiswa calon guru fisika di semester enam mengalami miskonsepsi tentang gravitasi. Milham \& Isabelle dalam Widodo \& Suhandi (2017) menyatakan bahwa sudah lama diketahui banyak mahasiswa yang mengalami kesulitan dengan konsep yang melibatkan gerakan di luar angkasa, dan bagaimana benda langit bergerak. Di negara turki, penelitian mengenai pemahaman konsep pada materi gravitasi salah satunya dilakukan oleh Mehmet KÜÇÜK yang mengungkapkan miskonsepsi yang dialami oleh mahasiswa, yakni mahasiswa calon guru fisika berpendapat bahwa di luar angkasa tidak ada gaya gravitasi karena tidak ada udara di luar angkasa (KÜÇÜK, 2005).

Dari 4 kategori pemahaman konsep tersebut dapat disimpulkan bahwa persentase tertinggi pemahaman konsep mahasiswa Pendidikan Fisika Universitas Sriwijaya yaitu pada kategori miskonsepsi. Kemudian kategori pemahaman konsep mahasiswa Pendidikan Fisika Universitas Sriwijaya dengan persentase terendah, yaitu paham konsep tetapi tidak yakin. Mahasiswa seharusnya lebih banyak membaca untuk memperluas pengetahuan dan pemahaman mengenai suatu materi dan dosen pembimbing mata kuliah perlu memilih strategi pembelajaran guna meremidiasi miskonsepsi pada mahasiswa. Berdasarkan analisis data didapat bahwa pada beberapa subkonsep materi gravitasi newton mahasiswa mengalami miskonsepsi, dan pada subkonsep materi yang lain mahasiswa tidak paham konsep, selanjutnya akan dideskripsikan bagaimana miskonsepsi mahasiswa pada setiap subkonsep dengan memfokuskan pada hasil wawancara dengan beberapa mahasiswa mengenai alasan dalam memilih jawaban.

\section{Konsep Arah Gaya Gravitasi}

Soal nomor 2, 5, 10, 12, 26 berhubungan dengan konsep arah gaya gravitasi miskonsepsi yang dialami oleh mahasiswa mencapai angka $39,57 \%$. Pada soal nomor 2 menanyakan tentang bagaimana arah gaya gravitasi yang dialami oleh dua orang astronaut yang melayang sangat jauh dari bintang dan planet di luar angkasa, mahasiswa mengalami miskonsepsi kebanyakan memilih jawaban $B$ dan D. Mahasiswa yang memilih jawaban B beranggapan bahwa kedua astronaut akan saling menjauhi satu sama lain karena dua astronaut tersebut saling ditarik oleh planet dan bintang yang sangat jauh. Untuk yang memilih jawaban D mahasiswa beralasan bahwa dua astronaut tersebut tidak mengalami gaya gravitasi, karena tidak ada benda besar disekita astronaut. Banyak juga mahasiswa yang tidak paham konsep yakni sebesar 44,68\%, hal ini dikarenakan mahasiswa menjawab jawaban yang salah, ada yang alasannya salah, tidak menggunakan alasan, dan skor CRI atau tingkat keyakinan mahasiswa dalam menjawab rendah.

Pada soal nomor 5 menanyakan bagaiaman arah gaya gravitasi pada bola yang dilemparkan dari sebuah sisi, pada soal nomor 5 ini 44,68\% mahasiswa paham konsep, tetapi sebanyak 25,55 $\%$ mahasiswa mengalami miskonsepsi. Mahasiswa yang mengalami miskonsepsi kebanyakan memilih jawaban A dengan alasan pada jawaban A menunjukan posisi A, dimana posisi A merupakan awal dari dilemparnya bola dengan alasannya mahasiswa menganggap bahwa dari awal bola dilempar bola sudah mengalami gaya gravitasi, sedangkan jawaban yang benar adalah B yang menunjukkan posisi B menuju pusat massa bumi.

Hal lain ditemukan pada soal nomor 12, yakni bagaimana arah gaya gravitasi yang dialami oleh sebuah asteroid dan ditemukan sebanyak 42,55 \% mahasiswa mengalami miskonsepsi dengan memilih jawaban $\mathrm{C}$ yakni bahwa arah gaya gravitasi asteroid menuju kearah bawah, tetapi disoal sudah ditentukan dimana arah pusat massa dan pusat geometric 
dan nyatanya mahasiswa masih beranggapan bahwa arah gaya gravitasi itu menuju kebawah dari sebuah benda.

\section{Besar Gaya Gravitasi}

Pada konsep ini terjadi miskonsepsi dengan rata-rata sebesar 43,09\%, dengan miskonsepsi terbesar dialami mahasiswa pada nomor 6 sebesar 63,83\%. Pada nomor 6 menanyakan bagaimana jika gaya gravitasi yang dialami seorang astronaut yang melayang di pesawat ruang angkasa yang mengorbit pada bumi, mahasiswa berpendapat bahwa pesawat ruang angkasa mempunyai jarak yang jauh terhadap bumi, sehingga tidak mengalami gaya gravitasi dari bumi. Alasan lain juga ditemukan yakni mahasiswa berpendapat bahwa diluar angkasa tidak ada gaya gravitasi. Begitu juga dengan nomor 13 dimana 38,30\% mahasiswa paham konsep tetapi 42,55 \% mahasiswa mengalami miskonsepsi pada nomor 13. Mahasiswa berangapan bahwa gaya gravitasi antara dua benda akan mendekati nol jika kedua benda tidak bergerak.

Pada soal nomor 9 menanyakan bagaimana besar gaya gravitasi yang dialami seseorang ketika berada di tiga posisi berbeda tetapi tetap berada dipermukaan bumi, sebesar 57,45 \% mahasiswa paham konsep pada nomor 9, tetapi sebesar $23,40 \%$ mahasiswa masih mengalami miskonsepsi.

\section{Hubungan Massa Terhadap Besar Gaya Gravitasi}

Pada subkonsep ini adalah pada nomor 18, 20, 25. Miskonsepsi yang dialami mahasiswa adalah sebesar 49,65\% dan 31,91\% tidak paham konsep. Pada soal nomor 18 menanyakan satelit mana yang akan mengalami gaya gravitasi lebih kuat jika massa satelit B bermassa tiga kali lebih besar dari satelit A dan ajrak orbit kedua planet terhadap bumi adalah sama, jawabannya adalah B karena massanya lebih besar. Tetapi 40,43 \% mahasiswa mengalami tidak paham konsep hal ini dikarenakan mereka menjawab salah, dan alasan juga salah disertai tingkat keyakinan dalam menjawab renda. Mahasiswa yang mengalami miskonsepsi sebesar 29,79 \% mereka beranggapan bahwa massa tidak akan mempengaruhi gaya gravitasi, dan tidak ada gaya gravitasi karena satelit yang selalu bergerak.

Hal lain ditemukan pada nomor 20 dimana mahasiswa yang mengalami miskonsepsi sebesar 57,45 \%. Mahasiswa beranggapan bahwa tidak ada gaya gravitasi di bulan. Hal ini sejalan dengan penelitian yang dilakukan oleh Bar mereka menemukan bahwa mahasiswa beranggapan ketika astronaut berada di permukaan bulan, maka astronaut tidak akan menginjak bulan karena bulan berada di luar angkasa, dan di luar angkasa tidak ada gaya gravitasi (Bar, Brosh, \& Sneider, 2015; Bar, Brosh, \& Sneider, 2015).

\section{Hubungan Jarak Terhadap Besar Gaya Gravitasi}

Nomor soal pada konsep ini adalah nomor 4, 23, dan 24. Miskonsepsi mahasiswa pada subkonsep ini adalah sebesar 40,43\%. Pada sub konsep ini mahasiswa tidak cermat dalam menentukan pengaruh jarak dalam mempengaruhi kuat lemahnya gaya gravitasi. Seperti pada soal nomor 4 yang menanyakan bagaimana jika posisi bumi diletakkan empat kali lebih jauh dari jarak bumi ke bulan sekarang, maka gaya graviasi antara bumi dan bulan akan bagaimana. Jawaban yang benar untuk soal nomor 4 adalah enam belas kali lebih lemah, dengan menggunakan persamaan gaya gravitasi dimana gaya gravitasi sama dengan hasil kali antara konstanta gravitasi dengan dua massa benda yang dibagi dengan kuadrat dari jarak antara dua buah benda, kebanyakan mahasiswa menjawab empat kali lebih lemah, dan mahasiswa Nampak menghiraukan arti dari persamaan yang ada.

Pada soal nomor 23 menanyakan tentang bagaimana kekuatan dari gaya gravitasi yang dialami oleh roket yang melakukan perjalanan yang semakin jauh ke luar angkasa. Jawaban yang benar adalah gaya gravitasi nya akan semakin mengecil yakni pilihan E, tetapi sebesar $46,81 \%$ mahasiswa mengalami miskonsepsi. Mahasiswa beranggapan bahwa gaya gravitasinya akan nol karena di luar angkasa tidak ada gaya gravitasi. Hal ini sejalan dengan penelitian yang dilakukan oleh KÜÇÜK yang menemukan bahwa mahasiswa beranggapan di luar angkasa tidak ada gaya gravitasi karena tidak ada udara di luar angkasa (KÜÇÜK, 2005) Pendapat lain juga ditemukan, yakni bahwa gaya gravitasi yang dialami roket akan nol ketika meninggalkan atmosfir bumi.

\section{Hubungan Jarak dan Massa terhadap Gaya gravitasi}

Konsep ini meliputi nomor soal 3, 7, 16, 19,22. Rata-rata miskonsepsi pada subkonsep ini adalah sebesar 40,85\%. Pada soal nomor 7 ditanyakan bagaimana gaya gravitasi antara dua 
satelit yang mengorbit pada sebuah planet dengan massa satelit $\mathrm{B}$ tiga kali lebih besar dari satelit A, dan jarak orbit satelit B juga tiga kali jarak satelit A mengorbit pada planet. Jawaban yang benar adalah A, yakni satelit A akan mengalami gaya gravitasi yang lebih kuat dari satelit B hal ini dikarenaka planet yang bermassa besar akan menarik benda yang mempunyai massa yang lebih kecil yakni satelit A, dan jarak satelit A meuju planet juga kecil. Tetapi 42,55 $\%$ mahasiswa mengalami miskonsepsi, mereka beranggapan ketika massa satelit B lebih besar makan gaya gravitasi yang dialami satelit B akan lebih besar pula, dengan hal ini dapat disimpulkan bahwa mahasiswa menghiraukan jarak sebagai penentu kuat lemahnya gaya gravitasi.

\section{Besar Gaya Gravitasi Tidak Terpengaruh Oleh Gaya Lain}

Miskonsepsi yang terjadi pada konsep ini adalah sebesar $37,94 \%$. Konsep ini meliputi soal nomor $1,8,11,14,15$, dan 17. Pada soal nomor 1 menanyakan faktor yang membuat benda tetap berada dipermukaan bumi selain gaya gravitasi. Pada soal nomor 1 ini mahasiswa yang mengalami miskonsepsi sebesar 44,68 \%, mahasiswa beranggapn bahwa magnet dari medan magnet bumi merupakan salah satu faktor yang mempengaruhi sebuah benda tetap berada di permukaan bumi.

Hal yang sama juga terjadi pada nomor 11 yang menanyakan bagaimana gaya gravitasi antara bumi dan matahari jika ukuran matahari diperkecil tetapi massanya tetap sama sehingga matahari akan lebih padat, 53,19\% mahasiswa paham konsep pada konsep ini, tetapi sebesar $38,30 \%$ mahasiswa mengalami miskonsepsi. Kebanyakan mahasiswa memilih jawaban A, yakni gaya gravitasi antara bumi dan matahri ketika mengalami kejadian tersebut akan menjadi lebih lemah, dengan alasan ketika ukurannya kecil maka jarak antara bumi dan matahari akan membesar, sehingga semakin besar jarak semakin lemah gaya gravitasi. Padahal untuk mengukur besar gaya gravitasi dari pusat massa bui menuju pusat massa matahari bukan dari permukaan bumi menuju permukaan matahari.

Mahasiswa yang mengalami miskonsepsi pada soal nomor 14 sebesar $48,94 \%$. Pada soal nomor 14 menanyakan diantara dua buah roket, roket mana yang akan mengalami gaya gravitasi lebih kuat jika setiap planet memiliki massa yang sama, dan jarak orbit roket terhadap bumi juga sama, tetapi planet A lebih padat dan ukurannya lebih kecil dari planet B. Kebanyakan mahasiswa menjawab pilihan B karena jarak permukaan B dan roket dekat, sehingga gaya graviasinya akan kuat. Mahasiswa tidak memahami bahwa besar gaya gravitasi dihitung dari pusat massa antara dua buah benda bukan dari permukaan dua buah benda. Ada juga yang menjawab pilhan A, dengan alasan bahwa kepadatan sebuah planet akan mempengaruhi kuat lemahnya gaya gravitasi.

Pada subkonsep ini mahasiswa banyak mengalami miskonsepsi, misalnya bahwa kepadatan sebuah planet mempengaruhi besarnya gaya gravitasi yang dialami planet tersebut. Medan magnet bumi merupakan salah satu faktor yang membuat benda tetap berada dipermukaan bumi.

\section{KESIMPULAN}

Berdasarkan analisis data hasil penelitian mengenai pemahaman konsep mahasiswa pendidikan fisika Universitas Sriwijaya semester IV pada materi gravitasi newton, dapat disimpulkan bahwa:

1. Persentase pemahaman konsep mahasiswa pada materi gravitasi newton beragam, yakni dengan persentase 28,10\% paham konsep, 4,79 \% paham konsep tetapi tidak yakin, 41,22 \% miskonsepsi, dan 25,89\% tidak paham konsep.

2. Persentase pemahaman konsep paling tinggi yaitu pada kategori miskonsepsi. Miskonsepsi tertinggi terdapat pada konsep hubungan massa terhadap besar gaya gravitasi yakni sebesar 49,65 \% .

3. Tingkat miskonsepsi yang dialami mahasiswa pada konsep Arah gaya gravitasi $39,57 \%$, Besar gaya gravitasi 43,09 \%, Hubungan massa terhadap besar gaya gravitasi 49,65\%, Hubungan jarak terhadap besar gaya gravitasi 40,43 \%, Hubungan jarak dan massa terhadap besar gaya gravitasi 40,85 \%, Besar gaya gravitasi tidak terpengaruh oleh hal lain 42,55\%.

Dari hasil penelitian ini dapat dinyatakan bahwa mahasiswa cenderung mengalami kesulitan dalam menyelesaikan soal konsep gravitasi newton. Hal ini terlihat dari tingginya persentase miskonsepsi dan tidak paham konsep mahasiswa. Adapun cara yang tepat untuk mengurangi miskonsepsi mahasiswa langkah 
awalnya adalah mengidentifikasi pemahaman konsep yang kemudian akan diketahui persentase dari kategori pemahaman konse sehingga dapat dipilih strategi pembelajaran yang dapat membantu mahasiswa menemukan dan menekankan konsep yang benar, guna menghindari miskonsepsi serta meremidiasi miskonsepsi yang dialami oleh mahasiswa.

\section{DAFTAR PUSTAKA}

Agustina, D., Syuhendri, \& Kistiono. (2016). Pengembangan Bahan Ajar Teks Perubahan Konseptual Berbasis Model Perubahan Konseptual Pada Materi Gerak Harmonik. Jurnal Inovasi dan Pembelajaran Fisika.

Bar, V., Brosh, Y., \& Sneider, C. (2016). Weight, Mass, and Gravity: Threshold Concepts in Learning Science. SUMMER 2016. Vol. 25, No. 1

Go"nen, S. (2008). A Study on Student Teeachers' Misconceptions and Scientifically Acceptable Conceptions About Mass and Gravity . Journal of Science Education and Technology 17(1):70-81.

Hakim, A. (2012). Student Concept Understanding of Natural Products Chemistry in Primary and Secondary Metabolies Using the Data Collecting Technique of Modified CRI. International Online Journal of Educational Sciences.

Hasan, S., Bagayoko, D., \& Kelley, E. L. (1999). Misconceptions and the Certainty of response Index (CRI). Phys Educ, 34(5), 294-299.

Hidayati, F. N., Akhsan, H., \& Syuhendri. (2016). Identifikasi Miskonsepsi Siswa Kelas X Pada Materi Elastisitas dan Hukum Hooke di SMA Negeri 1 Indralaya. Jurnal Inovasi dan Pembelajaran Fisika, 3(2), 1-9.

Jumini, S., Retyanto, B. D., \& Noviyanti, V. (2017). Identifikasi Miskonsepsi Fisika Menggunakan Three Tier Diagnostic Test Pada Pokok Bahasan Kinematika Gerak. Jurnal Kajian Pendidikan Sains.

Kallesta, K. S., \& Erfan, M. (2017). Analisis Faktor Penyebab Kesulitan Belajar IPA Fisika pada Materi Bunyi. Jurnal Pendidikan Fisika, 1(1).

Klammer, J. (1998). An Overview of Techniques for Identifying, Acknowledging and Overcoming
Alternate Conceptions in Physics Education. Klingestein Project Paper.

KÜÇÜK, M. (2005). Examination of Different Learning Levels of Students' and Student Science Teachers' Concepts About Gravity. Journal of Turkish Science Education, 2(1).

Marlis. (2015). Analisis Profil Pemahaman Konsep dan Konsistensi Konsepsi Siswa Kelas X SMA Negeri 1 Tilatang Kamang pada materi Fluida Statis. Prosiding Simposium Nasional Inovasi dan Pembelajaran Sains 2015 (SNIPS 2015)8 dan 9 Juni 2015, ( 413-416). Bandung, Indonesia.

Palmer, D. (2001). Student's Alternative Conceptions and Scientifically Acceptable Conceptions about Gravity. Internasional Journal of Science Education, 691-706.

Saleh, S. (2011). The Level of B.Sc.Ed Student's Conceptual Understanding of Newtonian Physics. Internasional Journal ofAcademic Research in Business and Social Sciences, 1(3), 249256.

Setyani, N. D., Suparni, C., \& Handhika, J. (2016). Analisis Instrumen Tes Pemahaman Konsep Fisika. Prosiding Seminar Nasional Quantum 2016 (pp. 369-372). Yogyakarta: Program Studi Pendidikan Fisika, Universitas Ahmad Dahlan.

Slavin, R. E. (2011). Psikologi Pendidikan. Jakarta: Indeks.

Sudjana, N. (2011). Penilaian Hasil Belajar Mengajar. Bandung.

Syuhendri. (2010). Pembelajaran Perubahan Konseptual: Pilihan Penulisan Skripsi Mahasiswa. Forum MIPA, 13(2), 133140.

Syuhendri. (2013). Analisis Pemahaman Konsep Mekanika Mahasiswa Program Studi Pendidikan Fisika Tahun 1 Dengan Menggunakan Force Concept Inventory Dan Certainty of Response Index (CRI). Indralaya: Universitas Sriwijaya.

Syuhendri, S. (2014). Konsepsi Alternatif Mahasiswa pada Ranah Mekanika: Analisis untuk Konsep Impetus dan Kecepatan Benda Jatuh. Jurnal Inovasi dan Pembelajaran Fisika 1(1), 56-57 
Syuhendri. (2018). The Development of Newtonian Mechanics Conceptual Change. Journal of Education and Learning, 12(3), 510-519.

Syuhendri, S., Andriani, N., \& Taufiq, T. (2019). Preliminary development of Conceptual Change Texts regarding misconceptions on Basic Laws of Dynamics. Journal of Physics: Conference Series 1166 (1), 012013.

Widodo, S. A., \& Suhandi, A. (2017). Pre Service Elementary Teachers Understanding on Force and Motion. Journal of Mathematics, Science and Technology Education, 2019, 15(8),

Williamson, K. E., Willougby, S., \& Prather, E. E. (2013). Development of the Newtonian Gravity Concept Inventory. Astronomy Education Review.
Williamson, K., Prather, E. E., \& Wiloughby, S. (2016). Applicability of The Newtonian Gravity Concept Inventory to Introductory College Physics Classes. American Journal of Physics, 84(6), 458-466.

Yunita. (2017). Identifikasi Miskonsepsi Mahasiswa Calon Guru Fisika pada Pokok Bahasan Rangkaian Listrik melalui Certainty of Response Index. Prosiding Seminar Nasional Pascasarjana (SNP) Unsyiah, (pp. B94B102). Banda Aceh, Indonesia.

Zahrah, Fihrin, \& Kendek, Y. (2017). Analisis Kemampuan Siswa Kelas XI SMA Negeri 5 Palu dalam Menyelesaikan Soal-Soal Kategori Analisis pada Konsep Dinamika Partikel. Jurnal Pendidikan Fisika Tadulako, 5(2), 3537. 